\title{
Rock Quarrying and Sustainable Environment Management
}

\author{
Dharmaratne P.G.R. \\ Department of Earth Resources Engineering, University of Moratuwa, Sri Lanka \\ dharme27@yahoo.com
}

\begin{abstract}
Nearly 90\% of Sri Lanka consists of Precambrian crystalline rocks except for a belt of Miocene sedimentary rocks along the north and North-west coast of the country. Gravel, sands and clays, particularly along river terraces, belonging to quaternary system are found resting on the Miocene formations and crystalline rocks. Precambrian crystalline rocks which most often occur as hills or mountains, consists of charnokites, migmatites and varieties of gneissic rocks. These rocks are suitable for road development and other constructions. Annual production of rock aggregates in the country is around 8 million cubic meters. During the recent times, due to large scale projects such as development of harbours, new air port and expressways, required large amount or aggregate material than usual. Colombo port city project alone will require about 3.5 million cubic meters of rock material within two years.,

There are over 2,500 Industrial Mining License (IML) grade quarries in Sri Lanka. The production vary between $1,500 \mathrm{~m} 3$ to $15,000 \mathrm{~m} 3$.per month. The operation of such a large number of rock quarries cause immense environmental damage. While development needs rock material, it is imperative to take remedial measures to mitigate the environmental damage caused by dust, noise, ground vibrations, fly rocks.

Spraying of water at quarry and crusher plant sites, spraying of water into crushers and conveyor belts will reduce dust immensely. Quarry and crusher plant sites should be well protected by erecting temporary mesh to prevent spreading of dust and a permanent tree barriers should be created as early as possible. Noise, ground vibration and fly rocks should be controlled by designing proper blasting geometries and proper explosive usage. Ground vibration which causes severe damage to buildings and structures can also be reduced by excavating trenches between the blast and the relevant structure. Mined out area should be rehabilitated by refilling and planting useful trees or if it is a pit, it should be converted in to a pond, for breeding fish or providing water for agriculture or converted into a municipal garbage dump by sealing the bottom with a impermeable clay layer.
\end{abstract}

Keywords: Rock quarrying, Ground vibration, Dust, Noise, Environment impacts mitigations

Proceedings of the International Forestry and Environment Symposium 2016, Department of Forestry and Environmental Science, University of Sri Jayewardenepura, Sri Lanka. 